\title{
Autosomal recessive limb-girdle muscular dystrophy type 2I
}

INSERM

\section{Source}

INSERM. (1999). Orphanet: an online rare disease and orphan drug data base. Autosomal recessive limb-girdle muscular dystrophy type 21. ORPHA:34515

A subtype of autosomal recessive limb-girdle muscular dystrophy that presents a highly variable age of onset and phenotypic spectrum typically characterized by slowly progressive proximal weakness of the pelvic and shoulder girdle musculature (predominantly affecting the lower limbs), frequently associated with waddling gait, scapular winging, calf and tongue hypertrophy, exercise-induced myalgia, and myog lobinuria and/or elevated creatine kinase serum levels. Abdominal muscle weakness, cardiomyopathy, respiratory muscle involvement and various brain abnormalities have also been reported. 